BRAULIO, CS; NÓBREGA, RSA; SILVA, LCV; CORREIA, AJ; SOUSA, CBC; PEREIRA, EG. 2020. Inoculation of diazotrophic bacteria in chicory. Horticultura Brasileira 38: 185-191. DOI - http://doi.org/10.1590/S0102-053620200211

\title{
Inoculation of diazotrophic bacteria in chicory
}

\author{
Caliane da S Braulio ${ }^{1 \mathbb{D}}$; Rafaela SA Nóbrega ${ }^{1 * \mathbb{D}}$; Luís Cláudio V Silva ${ }^{1 \mathbb{D}}$; Andreza de J Correia ${ }^{1 \mathbb{D}}$; Cheila \\ BC de Sousa ${ }^{1 \mathbb{D}}$; Elisângela G Pereira ${ }^{1 \mathbb{D}}$
}

${ }^{1}$ Universidade Federal do Recôncavo da Bahia (UFRB), Centro de Ciências Agrárias, Ambientais e Biológicas (CCAAB), Cruz das Almas-BA, Brasil; caliane.braulio@gmail.com; rafaela.nobrega@ufrb.edu.br (*author for correspondence); luismstt@yahoo.com.br; andrezza_coorreia@ hotmail.com; cheucarmo@gmail.com; eligoncalvespereira@hotmail.com

\begin{abstract}
Inoculating crops with diazotrophic bacteria constitutes a feasible biotechnological tool to reduce or even avoid the use of nitrogen fertilizers and to improve the nutritional status of crops. However, the potential use of such technology is limited due to the lack of studies in diverse vegetable crops. We evaluated the production of chicory (Cichorium intybus) in response to inoculation with diazotrophic bacteria in two soil classes. The experiments were performed under greenhouse conditions and under a completely randomized design. The treatments were constituted by strains UFRB FA34C2-2, UFLA 03-84 and INPA 0311B, and two control treatments (devoid of bacterial inoculation and with and without nitrogen fertilization). Two experiments were carried out, one using a soil classified as a dystrophic yellow Latosol (Oxisoil) and one using a Quartsandy Neosol (Typic Quartzipsamment). Chlorophylls $a, b$ and total; plant height; number of leaves; dry mass of the aerial portion; dry mass of roots; total dry mass; effectiveness; efficiency in addition to $\mathrm{N}$ and $\mathrm{P}$ gathering in the aerial portion, were evaluated 60 days after seeding. The inoculation with diazotrophic bacteria resulted in adequate production when compared to the control treatment without nitrogen fertilization and without inoculation. Diazotrophic bacteria showed potential supplying nitrogen to chicory plants and spare the use of nitrogen fertilization in both soil classes. The strain INPA 0311B, recommended for cowpea, promoted vegetal growth and increased the dry weight of the aerial portion in chicory, under both dystrophic yellow Latosol (Oxisoil) and Neossolo Quartzarênico (Typic Quartzipsamment), when cultivated under greenhouse conditions.
\end{abstract}

Keywords: Cichorium intybus, growth promoting rhizobacteria, organic production, sustainability.

\section{RESUMO}

\section{Inoculação de bactérias diazotróficas na chicória}

A inoculação de bactérias diazotróficas representa grande potencial biotecnológico por reduzir ou dispensar o uso de fertilizantes químicos nitrogenados e por melhorar as condições nutricionais da planta. No entanto, a potencialidade de aplicação desta tecnologia está limitada por carência de estudos em culturas diversas. Objetivou-se avaliar a produção do almeirão (Cichorium intybus) em resposta à inoculação com bactérias diazotróficas em duas classes de solos. Os experimentos foram realizados em casa de vegetação em delineamento inteiramente casualizado. Os tratamentos foram constituídos pelas estirpes UFRB FA34C2-2, UFLA 03-84 e INPA 0311B, e dois tratamentos controle (sem inoculação bacteriana e com e sem adubação nitrogenada). Foram realizados dois experimentos, um utilizando um solo classificado como Latossolo amarelo distrófico e outro utilizando Neossolo Quartzarênico. Aos 60 dias após a semeadura foram avaliados em ambos os experimentos: clorofila $a, b$ e total; altura; número de folhas; massa seca da parte aérea; da raiz e total, eficácia, eficiência e acúmulo de $\mathrm{N}$ e $\mathrm{P}$ na parte aérea. A inoculação com bactérias diazotróficas resulta em maior rendimento da produção, quando comparada ao tratamento controle sem adubação nitrogenada e sem inoculação. As bactérias diazotróficas apresentam potencial no fornecimento de nitrogênio às plantas de almeirão e dispensam o uso da fertilização nitrogenada nas duas classes de solo. A estirpe INPA 0311B, recomendada para o feijão-caupi, promove o crescimento vegetal e incrementa a parte aérea do almeirão, quando cultivado em Latossolo amarelo distrófico e Neossolo Quartzarênico em casa de vegetação.

Palavras-chave: Cichorium intybus, rizobactérias promotoras de crescimento, produção orgânica, sustentabilidade.

\section{Received on October 14, 2019; accepted on May 7, 2020}

$\mathrm{C}$ hicory (Cichorium intybus) is an herbaceous vegetable belonging to the Asteraceae family. It is originated in the Mediterranean Europe and stands out as a nutritive and medicinal vegetable. It differs from cichorium (Cichorium pumilum) by its bitter taste and more elongated and narrower leaves covered with hairs (Filgueira, 2013), being commonly known as bitter chicory. Chicory produces better under moderate temperatures around 14 to $24^{\circ} \mathrm{C}$ (Pereira et al., 2012).

Chicory is a leafy vegetable and nitrogen fertilization is extremely important for its development. However, the excessive or inadequate use of fertilizers in crop production, especially nitrogen fertilizers, has environmental implications (Biscaro et al., 2012) such as soil and water contamination and 
increase of nitrous oxide emissions, one of the greenhouse effect gases.

In addition to crop yield increment and food nutritional quality, modern society demands the consumption of products originated from a sustainable agriculture. Under such context, in leguminous crops such as soya (Glicine max) (Costa et al., 2014) and cowpea (Vigna unguiculata) (Ferreira et al., 2013; Costa et al., 2016), biological nitrogen fixation (BNF) mediated by selected symbiotic diazotrophic bacteria may substitute nitrogen fertilization, once it is considered an efficient nitrogen nutrition process in these crops. In nonleguminous crops diazotrophic bacteria may also contribute with associative $\mathrm{BNF}$, reducing nitrogen fertilization, as verified in corn (Zea mays) (Martins et al., 2018; Coelho et al., 2019) and sugar cane (Girio et al., 2015).

Biological nitrogen fixation through rhizobacteria in nonnodulating plants occurs by means of an association between plants and these microorganisms, which promote plant growth and supply nitrogen for these microorganisms which in turn benefit from carbohydrates delivered by the plant. Although this form of interaction is not as efficient as are leguminous plants, diazotrophic bacteria may promote plant growth through the solubilization of phosphates, production of exopolysaccharides and synthesis of phytohormones (Silva et al., 2016), such as auxins (indole-3-acetic acid, AIA) (Gopalakrishnan et al., 2015). Thus, the use of inoculants with associative bacteria may represent an alternative to develop vegetable cultivation systems, aiming to increase production through bio-control and growth promotion, which may reduce or avoid the use of mineral fertilization (Costa et al., 2014; Silva et al., 2016), in addition to the reduction of production cost and provide potential winnings for the farmer.

The use of inoculant with $\mathrm{N}$ fixing bacteria in leguminous plants is widely spread, their effects are verified (Costa et al., 2014; Girio et al., 2015; Gopalakrishnan et al., 2015; Silva et al., 2016; Lima et al., 2017; Costa et al., 2019), but their use in vegetables is incipient, once there is not yet an authorized inoculant by the Ministry of Agriculture, Livestock and Supply (MAPA) for this group of plants.

Information available concerning chicory is scarce, being one of the less studied vegetables in Brazil, when compared to the most commercialized vegetables (Biscaro et al., 2012). There are few studies regarding the use of inoculation with plant growth promoting rhizobacteria in vegetables. Production of tomato (Lycopersicon esculentum) in organic substrate inoculated with streptomyces promoted increased growth of seedlings (Sousa et al., 2009). In lettuce (Lactuca sativa), the efficiency of Azospirillum brasilense inoculation was verified when observing higher tolerance against virus and positive influence in plant height, stem diameter and fresh and dry weight of the aerial portion of the plant (Lima et al., 2017). Higher growth of the aerial portion of the plant and rooting was also observed in lettuce plantlets (Mangmang et al., 2015).

Studies have shown responsiveness of vegetal species which do not have authorized inoculants by the Ministry of Agriculture Livestock and Supply (MAPA), when inoculated with growth promoting diazotrophic bacteria (Mangmang et al., 2015; Lima et al., 2017; Braulio et al., 2019). Thus, it is important to increase the use of this technology as well as to select suitable strains for non-nodulating species, evaluating plant growth promotion, crop production and the potential of these microorganisms in diverse applications. Knowing the aptitudes of diazotrophic bacteria for fixing nitrogen and production of growth promoting plant hormones, we hypothesize that plants of chicory inoculated with diazotrophic bacteria show higher production of plant biomass. Thus, the present work had the objective to evaluate the production of chicory in response to inoculation with diazotrophic bacteria.

\section{MATERIAL AND METHODS}

Two experiments were performed in plastic pots filled with two soil classes: dystrophic yellow Latosol (Oxisoil)
(LAd) and Typic Quartzipsamment (NQ) (Santos et al., 2018).

The experiments were performed in greenhouse at the Agrarian, Environmental and Biological Sciences Center (CCAAB) at Federal University of Recôncavo da Bahia (UFRB), located in the county of Cruz das Almas, Bahia, Brazil (1240'19'S, 3906'23”W). During the experimental period in Lad (from November 2017 to January 2019), the temperature in the greenhouse varied from 31.1 to $29.5^{\circ} \mathrm{C}$ with $30.3^{\circ} \mathrm{C}$ in average and, during the experimental period in NQ (from March to April 2019), the temperature varied from 30.6 to $28.4^{\circ} \mathrm{C}$ with $29.5^{\circ} \mathrm{C}$ in average. Both, LAd and NQ were previously used under conventional system being planted with corn (Zea mays). Seeking to maintain the conditions of crop management in the region.

The first experiment was completed with LAd, sampled at the UFRB campus at $0.20 \mathrm{~m}$ depth. The chemical and physical characteristics of the soil were described as: $\mathrm{pH}\left(\mathrm{H}_{2} \mathrm{O}\right)=6.0$; organic matter $=12.8 \mathrm{~g} \mathrm{dm}^{-3}, \mathrm{P}($ Mehlich 1$)=$ $10.5 \mathrm{mg} \mathrm{dm}^{-3}, \mathrm{~K}^{+}=67.7 \mathrm{mg} \mathrm{dm}^{-3}, \mathrm{Ca}^{2+}=$ $0.7 \mathrm{cmol}_{\mathrm{c}} \mathrm{dm}^{-3}, \mathrm{Mg}^{2+}=0.3 \mathrm{cmol}_{\mathrm{c}} \mathrm{dm}^{-3}$, $(\mathrm{H}+\mathrm{Al})=2.0 \mathrm{cmol}_{\mathrm{c}} \mathrm{dm}^{-3}, \mathrm{SB}=1.2 \mathrm{cmol}_{\mathrm{c}}$ $\mathrm{dm}^{-3}$, effective $\mathrm{CEC}=1.2 \mathrm{cmol}_{\mathrm{c}}^{\mathrm{c}} \mathrm{dm}^{-{ }^{\mathrm{c}}}$, potential $\mathrm{CEC}=3.2 \mathrm{cmol} \mathrm{dm}^{-3}, \mathrm{~V}=$ $37.5 \%, \mathrm{Zn}^{2+}=5.05 \mathrm{mg} \mathrm{dm}^{-3}, \mathrm{Fe}^{2+}=49.05$ $\mathrm{mg} \mathrm{dm}{ }^{-3}, \mathrm{Mn}^{2+}=9.1 \mathrm{mg} \mathrm{dm}^{-3}, \mathrm{Cu}^{2+}=1.6$ $\mathrm{mg} \mathrm{dm}{ }^{-3}$ and $\mathrm{B}=0.28 \mathrm{mg} \mathrm{dm}^{-3}$; Sand $=533 \mathrm{~g} \mathrm{~kg}^{-1}$; Silt $=280 \mathrm{~g} \mathrm{~kg}^{-1}$; Clay $=$ $182 \mathrm{~g} \mathrm{~kg}^{-1}$.

In this first experiment the treatments were constituted by a strain under selection stage for cowpea inoculation: UFRB FA34C2-2 (Sousa, 2017), two strains already recommended and authorized by MAPA (Brasil, 2011) as inoculants for cowpea: INPA 0311B SEMIA 6462 (Bradyrhizobium elkanni) and UFLA 03-84 - SEMIA 6461 (Bradyrhizobium viridifuturi) (Costa et al., 2019), and two control treatments: one with nitrogen fertilization using urea $\left(135 \mathrm{mg} \mathrm{dm}^{-3} \mathrm{~N}\right.$ per plastic pot) (Steiner et al., 2010) and a second one without nitrogen fertilization. The experiment was set in a completely randomized design with four replicates, and one plant per replicate.

The second experiment was 
completed with samples of NQ collected at the campus of Federal Institute of Bahia (IF Baiano), in the county of Catu, Bahia, Brazil, at $0.20 \mathrm{~m}$ depth. The chemical and physical characteristics of the soil were described as: $\mathrm{pH}\left(\mathrm{H}_{2} \mathrm{O}\right)=$ 5.15; organic matter $=1.04 \mathrm{~g} \mathrm{dm}^{-3}, \mathrm{P}$ $\left(\right.$ Mehlich 1) $=6.4 \mathrm{mg} \mathrm{dm}^{-3}, \mathrm{~K}^{+}=14 \mathrm{mg}$ $\mathrm{dm}^{-3}, \mathrm{Ca}^{2+}=1.50 \mathrm{cmol}_{c} \mathrm{dm}^{-3}, \mathrm{Mg}^{2+}=0.34$ $\mathrm{cmol}_{\mathrm{c}} \mathrm{dm}^{-3},(\mathrm{H}+\mathrm{Al})=2.2 \mathrm{cmol}_{\mathrm{c}} \mathrm{dm}^{-3}, \mathrm{SB}=$ $1.88 \mathrm{cmol}_{\mathrm{c}} \mathrm{dm}^{-3}$, effective $\mathrm{CEC}=1.88$ $\mathrm{cmol}_{\mathrm{c}} \mathrm{dm}^{-3}$, potential CEC $=4.08 \mathrm{cmol}_{\mathrm{c}}$ $\mathrm{dm}^{-3}, \mathrm{~V}=46.1 \%, \mathrm{Zn}^{2+}=3.14 \mathrm{mg} \mathrm{dm}{ }^{-3}$, $\mathrm{Fe}^{2+}=114.5 \mathrm{mg} \mathrm{dm}{ }^{-3}, \mathrm{Mn}^{2+}=13.7 \mathrm{mg}$ $\mathrm{dm}^{-3}, \mathrm{Cu}^{2+}=0.89 \mathrm{mg} \mathrm{dm}^{-3}$ and $\mathrm{B}=0.17$ $\mathrm{mg} \mathrm{dm}^{-3} ;$ Sand $=575 \mathrm{~g} \mathrm{~kg}^{-1} ;$ Silt $=0.030$ $\mathrm{g} \mathrm{kg}^{-1}$; Clay $=0.118 \mathrm{~g} \mathrm{~kg}^{-1}$.

Treatments were constituted as described for the first experiment under a completely randomized design, with five treatments and ten replicates. Soil samples were dried and sieved in a $4 \mathrm{~mm}$ mesh, homogenized and conditioned in $3 \mathrm{~L}$ plastic pots.

In order to obtain the inoculum, bacteria were grown in semi-solid culture medium 79 inside a BOD (Biochemical Oxygen Demand) chamber for 4 days, at $25^{\circ} \mathrm{C}$, achieving the log growing phase $\left(10^{8} \mathrm{UFC} \mathrm{mL}\right)$. Chicory seeds of green leaves' spadona Radiche ${ }^{\circledR}$ were used in the experiments. Seeds were disinfected with alcohol $70 \%$ for 30 seconds and then, washed three consecutive times with sterilized distilled water. For each replicate $1 \mathrm{~mL}$ of the inoculant was added to the seeds. In control treatments without inoculation $1 \mathrm{~mL}$ of the semi-solid culture medium 79 without inoculum, was added.

Seeding was performed in polystyrene trays with 128 cells, with $18.5 \times 19.0 \times 11.0 \mathrm{~cm}$ length, width and depth, respectively. Each tray cell had a volume of $50 \mathrm{~mL}$, with two seeds being distributed on each cell. Seedlings were transplanted into $3.0 \mathrm{~L}$ pots 14 days after seeding. Plants were irrigated daily.

Plants were collected 60 days after seeding and the following variables were evaluated: chlorophyll $a$ (CLA), chlorophyll $b$ (CLB), determined with an electronic chlorophyll meter (clorofiLOG CFL 1030) Falker ${ }^{\circledR}$, the resulting dimensionless unit expressed as Index of Chlorophyll Falker (ICF) and the number of leaves (NL). Total chlorophyll (CLT) was obtained by adding the values from CLA + CLB. Then, plants were segmented in aerial portion and roots, conditioned in paper bags and set in a forced air oven at $60^{\circ} \mathrm{C}$, until attaining a constant weight in order to determine the dry mass, and to evaluate: dry mass of the aerial portion (DMAP), dry mass of roots (DMR), total dry mass (TDM), effectiveness of inoculation compared to the absolute control (EFSN) and efficiency of inoculation compared to fertilization with mineral N (EFCN).

Data of DMAP was used to calculate the effectiveness of the strains when compared to the control without EFSN and EFCN. Effectiveness was calculated using the formula: Effectiveness = (DMAP inoculated)*100/ (DMAP of the absolute control). Efficiency (EFCN) was calculated using the formula: Efficiency $=($ DMAP inoculated $) * 100 /$ (DMAP of plants fertilized with mineral N).

Samples of the dry aerial portion of the plants cultivated in LAd were used to determine contents (\%) of nitrogen (N) (GN) and phosphorus (P) (Gp). Samples of approximately $0.1 \mathrm{~g}$ DMAP were digested in a mixture of $3.0 \mathrm{~mL}$ concentrated sulfuric acid $\left(\mathrm{H}_{2} \mathrm{SO}_{4}\right)$ and $3 \mathrm{~mL} \mathrm{30 \%} \mathrm{hydrogen} \mathrm{peroxide}\left(\mathrm{H}_{2} \mathrm{O}_{2}\right)$. Then, the digested was diluted to 100 $\mathrm{mL}$ in distilled water, obtaining the extract to perform the analyses of $\mathrm{N}$ and P. Contents of N and P (\%) were determined by the spectrophotometric method of the phenol-hypochlorite

Table 1. Mean values for chlorophill $a$ (CLA), chlorophyll $b$ (CLB), total chlorophyll (CLT), number of leaves (NL), dry mass of the aerial portion (DMAP), dry mass of roots (DMR) and total dry mass (TDM) from chicory, in response to inoculation with diazotrophic bacteria when cultivated in dystrophic yellow Latosol (Oxisoil) (LAd) and Quartsandy Neosol (Typic Quartzipsamment) (NQ). Cruz das Almas, UFRB, 2017-2019.

\begin{tabular}{|c|c|c|c|c|c|c|c|}
\hline \multirow{2}{*}{ Treatment } & \multirow{2}{*}{ CLA } & \multirow{2}{*}{ CLB } & \multirow{2}{*}{ CLT } & \multirow{2}{*}{$\begin{array}{c}\mathrm{NL} \\
\text { (leaves/plant) }\end{array}$} & DMAP & DMR & TDM \\
\hline & & & & & \multicolumn{3}{|c|}{ (g/plant) } \\
\hline \multicolumn{8}{|c|}{ Lad } \\
\hline INPA 0311B & $30.85 a$ & $8.75 \mathrm{a}$ & $39.06 \mathrm{a}$ & $17.75 \mathrm{a}$ & $1.88 \mathrm{a}$ & $1.48 \mathrm{a}$ & $3.35 \mathrm{a}$ \\
\hline UFLA 03-84 & $27.86 \mathrm{~b}$ & $6.73 b c$ & $34.60 \mathrm{~b}$ & $15.00 \mathrm{~b}$ & $1.23 \mathrm{c}$ & $0.52 b$ & $1.74 \mathrm{c}$ \\
\hline UFRB FA34C2-2 & $29.03 \mathrm{ab}$ & $8.16 \mathrm{ab}$ & $35.48 \mathrm{ab}$ & $16.00 \mathrm{ab}$ & $1.54 \mathrm{~b}$ & $0.72 b$ & $2.26 \mathrm{~b}$ \\
\hline $\mathrm{S} / \mathrm{N}$ & $21.10 \mathrm{c}$ & $5.03 \mathrm{~d}$ & $29.13 c$ & $8.50 \mathrm{c}$ & $1.12 \mathrm{c}$ & $0.51 b$ & $1.63 \mathrm{c}$ \\
\hline $\mathrm{C} / \mathrm{N}$ & $22.78 \mathrm{c}$ & $6.35 \mathrm{~cd}$ & $29.13 \mathrm{c}$ & $6.75 \mathrm{c}$ & $1.76 \mathrm{c}$ & $0.51 b$ & $1.69 \mathrm{c}$ \\
\hline CV (\%) & 4.85 & 10.62 .0 & 4.19 .0 & 9.57 .0 & 7.15 .0 & 17.90 & 6.21 \\
\hline \multicolumn{8}{|c|}{ NQ } \\
\hline INPA 0311B & $30.59 \mathrm{a}$ & $8.65 \mathrm{a}$ & $39.24 \mathrm{a}$ & $11.00 \mathrm{a}$ & $0.71 \mathrm{a}$ & $0.20 \mathrm{a}$ & $0.91 \mathrm{a}$ \\
\hline UFLA 03-84 & $25.35 \mathrm{c}$ & $6.84 \mathrm{~b}$ & $39.19 \mathrm{c}$ & $9.00 \mathrm{bc}$ & $0.43 b$ & $0.14 \mathrm{~b}$ & $0.57 b$ \\
\hline UFRB FA34C2-2 & $29.23 \mathrm{ab}$ & $8.12 \mathrm{a}$ & $37.35 \mathrm{ab}$ & $9.40 \mathrm{~b}$ & $0.47 \mathrm{~b}$ & $0.15 b$ & $0.62 b$ \\
\hline $\mathrm{S} / \mathrm{N}$ & $24.28 \mathrm{c}$ & $5.46 \mathrm{c}$ & $29.74 \mathrm{c}$ & $7.70 \mathrm{c}$ & $0.16 \mathrm{~d}$ & $0.04 d$ & $0.21 \mathrm{~d}$ \\
\hline $\mathrm{C} / \mathrm{N}$ & $27.14 \mathrm{c}$ & $6.39 \mathrm{bc}$ & $33.53 b c$ & $8.10 \mathrm{c}$ & $0.35 \mathrm{c}$ & $0.10 \mathrm{c}$ & $0.44 \mathrm{c}$ \\
\hline CV (\%) & 9.66 & 10.78 & 9.36 & 13.74 & 11.28 & 24.28 & 24.28 \\
\hline
\end{tabular}

*Means followed by the same letter within the column are not statistically different, Tukey test at $5 \%$ probability. 
Table 2. Means of inoculation efficiency when compared with the control treatment without nitrogen fertilization and without inoculation (EFSN), efficiency of inoculation compared with fertilization with mineral nitrogen (EFCN), cultivated in dystrophic yellow Latosol (Oxisoil) (LAd) and Quartsandy Neosol (Typic Quartzipsamment) (NQ) and gathering of nitrogen (GN) and phosphorus (GP) in the aerial portion of chicory cultivated in Lad in response to inoculation with diazotrophic bacteria. Cruz das Almas, UFRB, 2017-2019.

\begin{tabular}{|c|c|c|c|c|c|c|}
\hline \multirow{3}{*}{ Treatment } & \multicolumn{2}{|r|}{ NQ } & \multicolumn{4}{|c|}{ LAd } \\
\hline & EFSN & EFCN & EFSN & EFCN & GN & GP \\
\hline & \multicolumn{4}{|c|}{$(\%)$} & \multicolumn{2}{|c|}{ (mg/plant) } \\
\hline INPA 0311B & $460.2 \mathrm{a}$ & $203.1 \mathrm{a}$ & $169.03 \mathrm{a}$ & $159.90 \mathrm{a}$ & $34.51 \mathrm{a}$ & $6.60 \mathrm{a}$ \\
\hline UFLA 03-84 & $285.6 \mathrm{~b}$ & $122.8 b c$ & $109.61 \mathrm{c}$ & $103.82 \mathrm{c}$ & $23.13 c$ & $4.36 \mathrm{c}$ \\
\hline UFRB FA34C2-2 & $319.9 b$ & $134.3 b$ & $137.96 b$ & $130.82 \mathrm{~b}$ & $27.68 b$ & $5.28 \mathrm{~b}$ \\
\hline $\mathrm{C} / \mathrm{N}$ & $100.0 \mathrm{c}$ & $45.86 \mathrm{~d}$ & $100.00 \mathrm{c}$ & $94.87 \mathrm{c}$ & $19.01 d$ & $3.67 \mathrm{c}$ \\
\hline $\mathrm{S} / \mathrm{N}$ & $232.3 b$ & $100.00 \mathrm{c}$ & $105.49 \mathrm{c}$ & $100.00 \mathrm{c}$ & $20.33 \mathrm{~cd}$ & $3.93 \mathrm{c}$ \\
\hline CV (\%) & 9.66 & 10.78 & 9.6 & 7.96 & 7.09 & 7.06 \\
\hline
\end{tabular}

*Means followed by the same letter in the column are not statistically different, Tukey test at $5 \%$ probability.

and the vanadium-molybdate for $\mathrm{P}$ (Faithfull, 2002). The N and P gathering in the aerial portion was calculated through $=$ mass of the aerial portion $(\mathrm{g})$ $*(\%$ de $\mathrm{N})$.

Data were submitted to variance analysis and $\mathrm{F}$ test. Means were compared by the Tukey test at $5 \%$ probability, using the statistical software "R" (R Development Core Team, 2018). Variables EFSN and EFCN were transformed in square root of $(x+0.5)$.

\section{RESULTS AND DISCUSSION}

Sources of nitrogen influenced production components of chicory cultivated in (LAd) and (NQ) $(\mathrm{p}<0.05)$. Sources of nitrogen influenced all variables analyzed.

Plants cultivated in both LAd and NQ, inoculated with strains INPA 0311B, UFRB FA34C2-2 and UFLA 03-84 showed superior indices of chlorophyll $a, b$ and total when compared to the control with mineral $\mathrm{N}$ and without $\mathrm{N}$ fertilization and without inoculation (Table 1).

The increase in chlorophyll may be related to the gathering of $\mathrm{N}$ in leaves (Ferreira et al., 2006), evidencing the results obtained in the present work (Table 2), where chicory plants with higher indices of chlorophylls $a, b$ and total, resulted in higher increments in the number of leaves (NL), thus promoting higher biomass (Table 1). Previous studies demonstrated that the index of chlorophyll may be used to evaluate the nutritional status of $\mathrm{N}$ in plants, signaling higher production crops (Ferreira et al., 2006; Silva et al., 2014).

Supplying nitrogen, through inoculation with rhizobium strains, had a positive effect in the synthesis of chlorophylls and consequently in the photosynthetic potential of plants in both soils tested. The applied dosage of $135 \mathrm{mg} \mathrm{N}$ per pot had an inferior effect when compared to the inoculation with bacterial strains, therefore showing these strains are efficient in fixing nitrogen in chicory plants (Table 1).

Chicory plants, inoculated with strains INPA 0311B and UFRB showed higher mean values for NL in plants cultivated in LAd. In NQ, a higher value for NL was verified for strain INPA 0311B (Table 1). Such results reflect the effect of these rhizobia in the provision of nutrients and consequently in the increment of the chicory biomass. Production of active growth regulators such as phytohormones is part of the metabolism of many bacterial species associated with plants and may be considered causal agents of growth and development modifications (Patil et al., 2011; Girio et al., 2015).

Control treatment with mineral $\mathrm{N}$ had no difference from the control without nitrogen fertilization and without inoculation for NL, in both studied soils (Table 1). The absence of differences between these treatments may be attributed to the capacity of native population of diazotrophic bacteria to fix nitrogen or promote growth in response to diverse mechanisms, such as the production of hormones for chicory plants. This species showed as being non-responsive to nitrogen fertilization for production of leaves, when cultivated in dystrophic red-yellow Latosol (Oxisol) under increasing dosages of $\mathrm{N}$ fertilization, without inoculation (Luz et al., 2017).

The number of leaves and production of dry weight are linked to the contents of $\mathrm{P}$ in the soil. This element is fundamental during photosynthesis, respiration and transfer of energy, cell division, cell growth and many other plant processes (Marschner, 2012). In this regard LAd showed $10.5 \mathrm{mg} \mathrm{dm}^{-3}$ of $\mathrm{P}$, this may also have contributed for a higher biomass production. Diazotrophic bacteria perform the solubilization of inorganic phosphates, solubilizing low solubility phosphate sources such as calcium phosphate, making those nutrients available for plant absorption (Costa et al., 2016). The higher quantity of leaves per plant results, in a general way, in higher dry mass of the aerial portion (DMAP) and consequently, higher crop production, as was observed in the present work (Table 1).

Similar to previous results observed by Ferreira et al. (2013), nutrients were not supplied to the plants, with the exception of the treatment with mineral $\mathrm{N}$. In addition to nitrogen fixation, bacteria perform diverse processes such as the solubilization of inorganic phosphates, influencing plant growth and nutrient gathering, as verified by Costa et al. (2015), when phosphate solubilizing bacteria improved plant growth in Oryza sativa, with increments of dry weight of the aerial portion and roots and nutrient gathering.

Concerning DMAP, DMR and TDM, the strain INPA 0311B showed higher biomass production in LAd than in NQ (Table 1).

An increment of $59.57 \%$ of DMAP and $34.46 \%$ of DMR was observed 
in LAd and increment of $22.54 \%$ of DMAP and $20 \%$ of DMR in NQ, when compared to the control treatment without nitrogen fertilization and without inoculation. Strain UFRB FA34C2-2 showed superior mean values than the strain UFLA 03-84 and the control treatments, and those did not differ between themselves for DMAP and TDM in LAd (Table 1). Treatments did not differ for DMR with exception of the strain INPA 0311B in LAd ( $p<0.01)$.

Increments of $22.54 \%$ of DMAP and $20 \%$ of DMR were observed in NQ, when compared to the control treatment without nitrogen fertilization and without inoculation. In plants cultivated in $\mathrm{NQ}$, the control with mineral $\mathrm{N}$ was superior only to the control without mineral fertilization and without inoculation for DMAP and DMR. In plants cultivated in NQ, strains UFRB FA34C2-2 and UFLA 03-84 did not differ between themselves for DMAP, DMR and TDM $(\mathrm{p}<0.01)$ (Table 1).

Inoculation with diazotrophic bacteria resulted in higher harnessing in the transport of $\mathrm{N}$ and $\mathrm{P}$, promoting increase in chicory DMAP. Increase in DMAP was also verified in tomato plants, inoculated with isolates of streptomyces (AC-29, AC-92 and AC-103) (Sousa et al., 2009) as well as in lettuce plants inoculated with Azospirillum brasilense (Lima et al., 2017), which may indicate the potential for promoting vegetal growth from rhizobacteria in vegetable crops.

The increment in DMAP corresponds to the NL and the gathering on $\mathrm{N}$ in the aerial portion of chicory (Crusciol et al., 2007). Inoculation with diazotrophic bacteria resulted in satisfactory production when compared to the control treatment without $\mathrm{N}$ fertilization and without inoculation (Table 1). Chicory, being a leafy vegetable, is very demanding in nitrogen fertilization (Steiner et al., 2010). The results observed in the present work show the potential of the strains tested to supply nutrients and produce mass increments in chicory.

Inoculation with diazotrophic bacteria provided nutrients for root absorption, supporting the nutritional status of chicory plants (Table 2). The increment of DMAP production on inoculated chicory plants, when compared to the control, may also be attributed to the production of growth regulating substances such as auxins, gibberellins and cytokinins (Gopalakrishnan et al., 2015), which participate in the processes of growth, development, nutrient mobilization and cell division in the plant, thus promoting higher production.

Inoculation promoted increment of the dry weight of roots enhancing absorption of available nutrients from the soil. Modifications in root morphology, promoted by phytohormones produced by microorganisms in the rhizosphere, supports the development of the radicular system and better exploration of the soil, which makes plants less susceptible to water and nutrient deficits (Silva et al., 2016). Amongst the effects produced by the indoleacetic acid synthetized by the bacteria, the development of lateral roots and primary root elongation was evidenced (Gopalakrishnan et al., 2015). The effects of inoculation on DMR were also verified by Sousa et al. (2009), in tomato plants inoculated with streptomyces AC-92.

The control treatment with mineral $\mathrm{N}$ did not differ from the control without fertilization and without inoculation for DMAP, DMR and TDM in chicory plants cultivated in LAd (Table 1). Lettuce (Lactuca sativa) plants cultivated in eutrophic red Latosol (Oxisol) under different dosages of $\mathrm{N}$ did not show significant influence for the production of DMAP and DMR (Nascimento et al., 2017). The absence of differences between these treatments may also be related with the capacity of native rhizobia to supply $\mathrm{N}$ to chicory plants, once this soil has no previous inoculation reported.

In respect to the efficiency of inoculation in the treatment control without $\mathrm{N}$ fertilization and without inoculation (EFSN) and inoculation efficiency in the treatment with $\mathrm{N}$ fertilization $(\mathrm{EFCN})$, the strain INPA 0311B was superior to all other strains in plants cultivated in LAd and NQ (Table 2). In LAd, strains UFRB FA34C2-2 and UFLA 03-84 and the control without
$\mathrm{N}$ fertilization and without inoculation were not different between themselves, with higher EFSN mean values when compared to the control with mineral N. Plants cultivated in NQ, inoculated with strains UFRB FA34C2-2, UFLA 03-84 and the control treatment without $\mathrm{N}$ fertilization and without inoculation did not differ from the treatment with mineral N. Strain UFRB FA34C2-2 showed higher EFCN when compared to the strain UFLA $03-84$ and the controls, which did not differ between themselves, in LAd. Plants cultivated in NQ and inoculated with the strains UFRB FA34C2-2 and UFLA 03-84, did not differ among themselves. The control treatment without $\mathrm{N}$ fertilization and without inoculation showed lower mean value than the control treatment with mineral $\mathrm{N}$.

The higher EFSN and EFCN observed in strain INPA 0311B, followed by UFRB FA34C2-2 in both soil classes (Table 2), may be related with the probable mechanisms performed by the diazotrophic bacteria which influenced the development and production of foliar mass in chicory (Table 2), influencing the production of growth promoting substances (Silva et al., 2016) as well as in the absorption of nutrients. Altogether evidencing the capacity for assimilation of atmospheric nitrogen by the inoculated rhizobium strains, and the consequent increase of DMAP.

Plants cultivated in LAd and inoculated with the strain INPA 0311B, followed by strain UFRB FA34C2-2, showed higher gathering of $\mathrm{N}$ and $\mathrm{P}$ in the aerial portion of the plant, when compared to all other treatments. Control treatments with mineral $\mathrm{N}$ and without $\mathrm{N}$ fertilization and without inoculation did not differ between themselves for GN and GP (Table 2). Crusciol et al. (2007) affirmed that the increase in dry weight of the aerial portion may be associated with a higher gathering of total $\mathrm{N}$ in plant leaves, once this element works increasing the index of chlorophyll, foliar area and photosynthesis. Such result was evidenced by the values of DMAP inoculated with rhizobia (Table 1), due to the Biological Nitrogen Fixation 
(BNF). Some other influences due to biological process not evaluated in the present work may also occur, such as solubilization of phosphates, synthesis of phytohormones and production of exopolysaccharides, as previously evaluated in previous studies using the same strains as in the present work (Gopalakrishnan et al., 2015; Silva et al., 2016; Sousa, 2017).

Inoculated plants showed higher mean values for GN, when compared to values observed by Almeida et al. (2013), in chicory plants under nutritive solutions supplemented with micro-nutrients $\left(20.1 \mathrm{mg} \mathrm{plant}^{-1}\right)$, in the absence of inoculation. However, the values of GP were lower (Table 2) than those found by these authors (23.1 mg plant ${ }^{-1}$ ), when compared with all treatments evaluated in the present work. In a general manner, low values for GP observed in plants cultivated in LAd, independently of the treatments, may be related with the availability of nutrients in the soil, once plants were cultivated without the addition of mineral or organic fertilization, except the control treatment with mineral $\mathrm{N}$. The absence of mineral fertilization $(\mathrm{P}$ and $\mathrm{K}$ ) or organic fertilization may have caused a reduction in nutrient absorption, limiting vegetative growth of plants and consequently diminishing dry weight production and nutrient gathering, when compared with plants fertilized with mineral or organic sources (Biscaro et al., 2012; Pereira et al., 2012).

Another issue that may have limited the DMAP in both soils was the temperature, once this species produces better under moderate temperatures from 14 to $24^{\circ} \mathrm{C}$ (Pereira et al., 2012), while the mean temperatures registered in the greenhouse during the present work were of $30.3^{\circ} \mathrm{C}$ in LAd and $29.5^{\circ} \mathrm{C}$ in NQ.

In both soil classes, evaluating the production of chicory inoculated with diazotrophic bacteria, strains INPA 0311B and UFRB FA34C2-2, when compared to the control without $\mathrm{N}$ fertilization and without inoculation, presented mean values near or higher than the control treatment with mineral $\mathrm{N}$ (Table 1). The strain INPA 0311B, reacted positively for production of NL, DMAP, DMR and TDM in both soil classes studied, without the need for $\mathrm{N}$ fertilization, which besides representing an extra cost may pollute the environment if incorrectly used. It is important to mention the need for further investigation in order to verify the effect of inoculation under different soil and climatic conditions.

The strain INPA 0311B, authorized and recommended for cowpea, was more efficient to increase the production of aerial portion in plants of chicory while plants inoculated with the strain INPA 0311B showed the highest concentrations of $\mathrm{N}$ and $\mathrm{P}$ in the aerial portion. Chicory yield in soils without amendments and fertilization increased with the inoculation of diazotrophic bacteria. Diazotrophic bacteria showed potential to supply nitrogen to chicory plants.

\section{REFERENCES}

ALMEIDA, TBF; PRADO, RM; FLORES, RA; POLITI, LS; BARBOSA, J C. 2013. Avaliação nutricional do almeirão cultivado em soluções nutritivas suprimidas de macronutrientes, Scientia Agraria Paranaensis 12: 211-220.

BISCARO, GA; SILVA, JA; ZOMERFELD, PS; MOTOMIYA, AVA; GOMES, EP; GIANCON, GM. 2012. Produção de almeirão em função de níveis de fertirrigação nitrogenada e disposição de mangueiras gotejadoras nos canteiros, Ciência Rural.

BRASIL. 2011. Instrução normativa $n^{\circ} 13$, de 24 de março de 2011 anexo - protocolo oficial para avaliação da viabilidade e eficiência agronômica de cepas, inoculantes e tecnologias relacionados ao processo de fixação biológica de nitrogênio em leguminosas. Diário Oficial da República Federativa do Brasil, n ${ }^{\circ} 58$ de 25 mar. Accessed June 19, 2019.

BRAULIO, CS; NÓBREGA, RSA; MOREIRA, FM; ANJOS, ASJC; SILVA, JJ; ROCABADO, JMA. 2019. Growth response of Bauhinia variegata $\mathrm{L}$. to inoculation and organic fertilization. Revista Árvore 43: 1-10.

COELHO, BA; DIAS, VC; PELÚZIO, JM; SOUZA, CM; SIQUEIRA, GB; SANTOS, WF. 2019. Produtividade do milho cultivado em baixa latitude na entressafra inoculado com Azospirillum brasilense com diferentes doses de nitrogênio. Journal of Bioenergy and Food Science 6: 18-28.

COSTA, EM; CARVALHO, F; ESTEVES, JA; NÓBREGA, RSA; MOREIRA, FMS. 2014. Resposta da soja a inoculação e co-inoculação com bactérias promotoras do crescimento vegetal e Bradyrhizobium. Enciclopédia Biosfera 10: 1678.
COSTA, EM; CARVALHO, TS; GUIMARÃES, AA; LEÃO, ACR; CRUZ, LM; BAURA, VA; LEBBE, L; WILLEMS, A; MOREIRA, FMS. 2019. Classification of the inoculant strain of cowpea UFLA03-84 and of other strains from soils of the Amazon region as Bradyrhizobium viridifuturi (symbiovar tropici). Brazilian Journal of Microbiology 50: 335-345.

COSTA, EM; CARVALHO, F; NÓBREGA, RSA; SILVA, JS; MOREIRA, FMS. 2016. Bacterial strains from floodplain soils perform different plant-growth promoting processes and enhance cowpea growth. Scientia Agricola 73: 301-310.

COSTA, EM; LIMA, W; OLIVEIRA-LONGATT, S; SOUZA, FSM. 2015. Phosphate-solubilising bacteria enhance Oryza sativa growth and nutrient accumulation in an oxisol fertilized with rock phosphate. Ecological Engineering 83: 380-385

CRUSCIOL, CAC; SORATTO, RP; SILVA, LM; LEMOS, LB. 2007. Fontes e doses de nitrogênio para o feijoeiro em sucessão a gramíneas no sistema plantio direto. Revista Brasileira de Ciência do Solo 31: 1545-1552.

FAITHFULL, NT. 2002. Methods in agricultural chemical analysis: a practical handbook. Wallingford: CABI Publishing, p.262.

FERREIRA, MMM; FERREIRA, GB; FONTES, PCR; DANTAS, JO. 2006. Índice Spad e teor de clorofila no limbo foliar do tomateiro em função de doses de nitrogênio e da adubação orgânica, em duas épocas de cultivo. Revista Ceres 35: 83-92.

FERREIRA，LVM; NÓBREGA，RSA; NÓBREGA, JCA; AGUIAR, FL; MOREIRA, FMS; PACHECO, LP. 2013. Biological nitrogen fixation in production of Vigna unguiculata L. Walp. Family farming in Piauí, Brazil. Journal of Agricultural Science 5: 153-160.

FILGUEIRA, FAR. 2013. Novo manual de olericultura: agrotecnologia moderna na produção e comercialização de hortaliças. 3ed. Viçosa: UFV. 421p.

GIRIO, LAS; DIAS, FLF; REIS, VM; URQUIAGA, S; SCHULT, N; BOLONHEZI, D; MUTTON, MA. 2015. Bactérias promotoras de crescimento e adubação nitrogenada no crescimento inicial de cana-de-açúcar proveniente de mudas pré-brotadas. Pesquisa Agropecuária Brasileira 50: 33-43.

GOPALAKRISHNAN, S; SATHYA, A; VIJAYABHARATHI, R; VARSHNEY, RK; GOWDA, CLL; KRISHNAMURTHY, L. 2015. Plant growth promoting rhizobia: challenges and opportunities. 3 Biotech 5: 355-377.

LIMA, AA; VENTUROSO, LR; SILVA, BAA; GOMES, AF; SCHIMIDT, O. 2017. Eficiência da inoculação de Azospirillum brasilense associado com enraizador no crescimento e na produção de alface. Revista Verde de Agroecologia e Desenvolvimento Sustentável 12: 233-240.

LUZ, SROT; MARTINS, JKD; SILVA, CA; TURCATO, CT. 2017. Doses crescentes de adubação nitrogenada na cultura do almeirão cultivado na presença e ausência de mulching na amazônia ocidental. Agrarian Academy 


\section{4: 185 .}

MANGMANG, JS; DEAKER, R; ROGERS, G. 2015. Early seedling growth response of lettuce, tomato and cucumber to Azospirillum brasilense inoculated by soaking and drenching. Horticultural Science 42: 37-46.

MARSCHNER, P. 2012. Marschner's mineral nutrition of higher plants.3ed. Academic Press, Australia: University of Adelaide. 649p.

MARTINS, MR; JANTALIA, CP; REIS, VM; DÖWICH, I; POLIDORO, JC; ALVES, BJMR; BODDEY, RM; URQUIAGA, S. 2018. Impact of plant growth-promoting bacteria on grain yield, protein content, and urea- $15 \mathrm{~N}$ recovery by maize in a Cerrado Oxisol. Plant Soil 422: 239-250.

NASCIMENTO, MV; SILVA JUNIOR, RL; FERNANDES, LR; XAVIER, RC; BENETT, KSS; SELEGUINI, AS; BENETT, CGS. 2017. Manejo da adubação nitrogenada nas culturas de alface, repolho e salsa. Revista de Agricultura Neotropical 4: 65-71.

PATIL, NB; GAJBHIYE, M; AHIWALE, SS;
GUNJAL, AB; KAPADNIS, BP. 2011 Optimization of indole 3 acetic acid (IAA) production by Acetobacter diazotrophicus L1 isolated from Sugarcane. International Journal of Environmental Sciences 2: 307-314.

PEREIRA，DC; GRUTZMACHER，P; BERNARDI, FH; MALLMANN, LS; COSTA, LAM; COSTA, MSSM. 2012. Produção de mudas de almeirão e cultivo no campo, em sistema agroecológico. Revista Brasileira de Engenharia Agrícola e Ambiental 16: 1100-1106.

R Core Team (2018). 2018. R: A language and environment for statistical computing. $R$ Foundation for Statistical Computing, Vienna, Austria. URL https: //www.R-project.org/. Accessed May 15, 2019.

SANTOS, HG; JACOMINE, PKT; ANJOS, LHC; OLIVEIRA, VA; LUMBRERAS, JF; COELHO, MR; ALMEIDA, JA; ARAÚJO FILHO, JC; OLIVEIRA, JB; CUNHA, TJF. 2018. Sistema Brasileiro de Classificação de Solos 5ed. Brasília: Embrapa, 356p.

SILVA, FG; SANTOS, IB; SOUZA, AJ; FARIAS,
ARB; DINIZ, WPS; KUKLINSKY-SOBRAL, J; FREIRE, MBGS. 2016. Bioprospecting and plant growth-promoting bacteria tolerant to salinity associated with Atriplex nummularia L. in saline soils. African Journal of Microbiology Research 10: 1203-1214.

SILVA, MA; SANTOS, CM; VITORINO, HS; RHEIN, ALF. 2014. Pigmentos fotossintéticos e índice SPAD como descritores de intensidade do estresse por deficiência hídrica em canade-açúcar. Bioscience Journal 30: 173-181.

SOUSA, CS; SOARES, ACF; GARRIDO, MS. 2009. Produção de mudas de tomateiro em substrato orgânico inoculado e incubado com estreptomicetos. Bragantia 68: 195-203.

SOUSA, JX. 2017. Promoção do crescimento vegetal por bactérias oriundas de solos com histórico de deposição de manipueira. Cruz das Almas: UFRB. 61p. (M.Sc. Thesis).

STEINER, F; LANA, MC; ECHER, MM; TIAGO, ZOZT; FRANDOLOSO, J F. 2010. Acúmulo de nitrato e produção de duas cultivares de almeirão em função da adubação nitrogenada. Global Sciene and Technology 3: 60-69. 